logy Department on the production of a silica standard of length. In 1912 he was transferred to the Physics Department to take charge of the thermometer testing work, then taken over from Kew Observatory, and of radium measurements.

As a captain in the London Electrical Engineers R.E.(T.), he was called to the colours in August 1914 and for a time served at a Thames Estuary Station on searchlight work. Later he transferred to the Aeronautical Inspection Directorate of the Air Ministry, in which organization he rose ultimately to the position of chief inspector of materials, with the rank of major. It was in this position that he applied $\mathrm{X}$-rays to the examination of various types of timber splices. The A.I.D. gave him much experience in the handling of men of many types and of committee work, which appealed especially to him. On his return to the National Physical Laboratory, he took charge of the Physics Department and was appointed superintendent in 1922. He was primarily interested in the administrative side of the work and for more than twenty years he was chairman of the Library Committee of the Laboratory.

Kaye was especially interested in the British X-ray and Radium Protection Committee, and took an active part in the deliberations of the International X-Ray and Radium Protection Commission of the various Congresses of Radiology. He gave the eighth Caldwell Memorial Lecture before the American Roentgen Ray Society in Montreal in 1927, and his presidential address to the British Institute of Radiology in 1929 was entitled "Radiology, Medieval and Modern". At one time thermal measurements attracted his attention, and a number of papers were published jointly with various colleagues.

It was not, however, until the need arose for the inclusion of the subject of sound in the activities of the National Physical Laboratory that Kaye found scope for his special talents. He took great pride in the design of the new Acoustics Laboratory, and neither time nor money was spared to ensure that Great Britain should be in the forefront as regards equipment for the study of the acoustics of buildings and allied problems. Special attention was devoted to noise measurements, on which subject a number of papers was published. These constituted the basis of his presidential address to Section A of the British Association at the Nottingham meeting in 1937. His election to the presidency of Section A afforded him the deepest satisfaction, and much time was spent in the preparation of his address, which was lavishly illustrated by experiments and with a cinematograph film.

Soon after Kaye became superintendent of the Physical Department of the National Physical Laboratory, it had become apparent that a rehousing of the Department was necessary. $\mathrm{He}$ undertook wholeheartedly the task of specifying the requirements of the Department and, in conjunction with the then Office of Works, in preparing the basic plans of the present structure. Many times the schemes were turned down for reasons of economy. This delay did not prevent Kaye from keeping the plans abreast of modern requirements, and features of the building have since been incorporated in other new laboratories built in Great Britain.

Kaye was the recipient of many honours, which included the Mackenzie Davidson Medal of the Royal Society of Medicine and the Silvanus Thompson Medal of the British Institute of Radiology. He was elected a fellow of the Royal Society in 1939.

Ezer Griffiths.

\section{Prof. Charles Laubry}

By the death of Prof. Charles Laubry of Paris at the age of sixty-eight, the announcement of which rapidly follows that of Prof. Wenckebach's (see NATURE, March 1, 1941, p. 260), though the exact date is unascertainable in present circumstances, medical science has lost another pioneer in módern cardiology, and particularly in the application of radiology to diseases of the heart.

Laubry was a pupil of the late Prof. Vaquez of Paris, whose school exercised a great influence over current cardiological teaching throughout Europe and Latin America, though less in Great Britain and the United States. His literary output was considerable. His principal works in chronological order were: "Leçons de sémiologie cardiovasculaire. Les troubles fonctionnels" (1924), "Traité des maladies congénitales du cour" in collaboration with Pezzi of Milan (1926), and "Radiologie clinique du cœur et des grands vaisseaux" in collaboration with Cottenot, Routier and Heim de Balsac (1939). He was also editor of the Archives des maladies du cour.

In addition to his cardiological work, he was the author of the section on the symptomatology of diseases of the respiratory system in the third volume of the "Nouveau Traité de Pathologie Interne" (1938).

Like Prof. Wenkebach, Laubry had many friends in Great Britain. He delivered the Saint Cyres Lecture at the National Heart Hospital in 1937, and he was an honorary member of the Cardiac Society. $\mathrm{He}$ was elected an honorary foreign fellow of the Royal Society of Medicine in 1939.

WE regret to announce the following deaths :

Mr. N. C. Brown, known for his work on the distribution and habits of North American birds, on March 20, aged eighty-four.

Sir James Frazer, O.M., F.R.S., the well-known anthropelogist and author of the "Golden Bough", and Lady Frazer, on May 7, aged eighty-seven.

Prof. G. L. Gulland, C.M.G., emeritus professor of medicine in the University of Edinburgh, on May 4.

Prof. L. Kahlenberg, formerly professor of chemistry in the University of Wisconsin, on March 19, aged seventy-one.

Prof. Nikolaj Konstantinovic Koltzoff, director of the Moscow Institute of Experimental Biology, aged sixty-nine ; in making this announcement in NATURE of April 19, p. 474, Prof. Koltzoff's surname was omitted.

Prof. A. C. Pereira, professor of toxicology in the University of Lisbon, on December 20, aged seventythree. 